\title{
X-ray Fluorescence (XRF) Geochemical Investigation of Delta Steel Company (DSC), Ovwian-Aladja, western Niger Delta, Nigeria, Steelmaking Slag for use as Iron making Blastfurnace Feed and Fertilizer
}

\author{
Napoleon A. Wessey \\ Department of Geology, \\ Niger Delta University, Wilberforce Island, \\ Amassoma, Nigeria \\ Email: napwessey [AT] yahoo.com
}

\begin{abstract}
This work investigated the bulk geochemistry of fifteen (15) samples of Delta Steel Company (DSC) dump slag produced by the direct reduction steelmaking process, using the $X$-ray fluorescence spectroscopy (XRF) method and glass discs prepared from each of the fifteen test slag samples. The results indicate the presence of major amounts of $\mathrm{CaO}(36.62 \%), \mathrm{MgO}(9.77 \%), \mathrm{Fe}_{2} \mathrm{O}_{3}(27.32 \%)$, $\mathrm{SiO}_{2}(19.86 \%), \mathrm{Al}_{2} \mathrm{O}_{3}(5.43 \%)$, low amounts of $\mathrm{MnO}(1.46 \%)$, $\mathrm{TiO}_{2}(0.42 \%), \mathrm{Cr}_{2} \mathrm{O}_{3}(0.17 \%), \mathrm{P}_{2} \mathrm{O}_{5}(0.53)$, and minor amounts of $\mathrm{SO}_{3}(0.04)$. The geochemical composition of the slag indicates suitable use as iron making blastfurnace feed and as fertilizer. The low amount of MnO in the slag is advantageous as it can reduce the disadvantage of probably causing refractory lining destruction in the presence of a notable amount of $\mathrm{K}_{2} \mathrm{O}$. The use of this slag would contribute to the conservation of natural steelmaking resources, improved crop yeild and reduction in $\mathrm{CO}_{2}$ emission in the company environment.
\end{abstract}

Keywords--- Steelmaking slag, x-ray fluorescence spectroscopy, geochemistry, blast furnace feed, fertilizer

\section{INTRODUCTION}

Steelmaking slag is the by-product of processing molten iron into a specific type or grade of steel. In iron and steel manufacture, the fusion of a flux material such as limestone, dolomite, or lime, etc with ash from coke, and iron ore/scrap iron produces slag. The steelmaking slag at the Delta Steel Company (DSC) Ovwian-Aladja, was produced using the direct reduction steel making process. The process involved the use of the Mfamosing limestone and company direct reduced iron/scrap. The direct reduced iron was produced from Liberian iron ore.

Results of bulk samples X-ray fluorescence spectroscopic (XRF) studies on steelmaking slags and Portland cement clinkers by many researchers indicated the presence of $\mathrm{SiO}_{2}, \mathrm{Al}_{2} \mathrm{O}_{3}, \mathrm{CaO}, \mathrm{Fe}_{2} \mathrm{O}_{3}, \mathrm{TiO}_{2}, \mathrm{MnO}, \mathrm{MgO}, \mathrm{K}_{2} \mathrm{O}, \mathrm{Cr}_{2} \mathrm{O}_{3}, \mathrm{P}_{2} \mathrm{O}_{5}$, $\mathrm{SO}_{3}$ and $\mathrm{Na}_{2} \mathrm{O}$. This showed the reported geochemical similarity between steelmaking slags and Portland cement clinkers (Yamaguchi and Tagaki, (1968); Gutt, (1971); Thom and Wood, (1973); Pugh and Fletcher, (1973); Medlan, (1973); Lee, (1974); Atwell, (1974); Joseph and Haddad, 1973, 1975); Barton, (1975); Piret and Lesgardeue, (1975); Emery, (1977); Kristman(1977); Blunk and Geissler, (1980); Scott, et al,(1986); Shi, et al., (2004), Shen, et al., (2009), Barra et al., (2001); Sitien et al., (2009); Branca, T. A. and Colla, V(2012) have recent published data on the chemistry of steelmaking slags and their uses. 
Table 1: Chemical composition of some BOF, EAF, and Ladle Slags (Shi, 2004), (Shen et al, 2009) ${ }^{+}$, (Barra et al, 2001 $\}^{*}$, (Setien et al, 2009)** in comparison with DSC slag composition.

\begin{tabular}{|l|c|c|c|c|}
\cline { 2 - 5 } $\begin{array}{l}\text { Oxide } \\
\text { Composition \% }\end{array}$ & \multicolumn{4}{|c|}{ Slag type } \\
\cline { 2 - 5 } $\mathrm{S}_{\mathrm{I}} \mathrm{O}_{2}$ & $8-20$ & $9-20$ & $2-35$ & $\begin{array}{l}\text { DOF } \\
18-22.42\end{array}$ \\
\hline $\mathrm{T}_{\mathrm{I}} \mathrm{O}_{2}$ & $0.4-2$ & - & - & $0.39-0.46$ \\
\hline $\mathrm{Al}_{2} \mathrm{O}_{3}$ & $1-6$ & $2-9$ & $5-35$ & $4.50-6.00$ \\
\hline $\mathrm{FeO}$ & $10-35$ & $15-30$ & $0-15$ & - \\
\hline $\mathrm{Fe}_{2} \mathrm{O}_{3}$ & - & - & - & \\
& $(38.6)^{+}$ & $(32.56)^{*}$ & $(1.6-3.3)^{* *}$ & $17.93-41.00$ \\
\hline $\mathrm{MnO}$ & $2-8$ & $3-8$ & $0-5.0$ & $1.03-2.03$ \\
\hline $\mathrm{MgO}$ & $5-15$ & $5-15$ & $1-10$ & $7.05-13.43$ \\
$\mathrm{CaO}$ & $30-55$ & $35-60$ & $30-60$ & $27.23-44.20$ \\
\hline $\mathrm{P}_{2} 0_{5}$ & $0.2-2$ & $0.0-0.3$ & $0.1-0.4$ & $0.44-0.77$ \\
\hline $\mathrm{SO}_{3}$ & $0.1-0.2$ & $0.1-0.2$ & $0.1-1$ & $0.00-0.14$ \\
\hline Free $\mathrm{CaO}$ & - & - & - & \\
\hline
\end{tabular}

Shi et al (2004) presented the iron present as FeO in the three slag types while Shen et al, (2009); Barra et al, (2001); and (Setien et al, (2009) reported iron found as $\mathrm{Fe}_{2} \mathrm{O}_{3}$. Shen et al., Barra et al., and Sitien et al., cited in Yildirim and Prezzi, (2011), also reported that BOF, EAF and Ladle slags were composed of $38.6 \%, 32.56 \%$ and 1.6- $3.3 \%$ of $\mathrm{Fe}_{2} \mathrm{O}_{3}$ respectively. The iron found in DSC slag was reported as $\mathrm{Fe}_{2} \mathrm{O}_{3}$ and the slag samples were composed of $\mathrm{Fe}_{2} \mathrm{O}_{3}$ ranging in occurrence between $17.93 \%$ and $41.00 \%$.

The main chemical constituents of basic-oxygen-furnace (BOF) steelmaking slag are reported as $\mathrm{CaO}, \mathrm{FeO} / \mathrm{Fe}_{2} \mathrm{O}_{3}$, and $\mathrm{SiO}_{2}$ [Wachsmuth, et al, (1981); Schoenberger, (2001); Juckes, (2003); Shi, (2004); Yildirim and Prezzi, (2011); Gautier et al, (2013; Piatak et al, (2015)]. The conversion of molten iron into steel during the steelmaking process is not complete, a percentage of the iron $(\mathrm{Fe})$ in the hot metal could not be recovered into the steel produced (Yildirim and Prezzi, 2011). This oxidized iron was observed in the chemical composition of the BOF slag. The iron oxide $\left(\mathrm{FeO}^{\mathrm{F}} \mathrm{Fe}_{2} \mathrm{O}_{3}\right)$ content of BOF slag was as high as $38 \%$ (refer to Table 1 ) which was determined by the efficiency of the furnace (Gauntier et al, 2013). This was the amount of oxidized iron that could not be recovered during the conversion of molten iron into steel. The silica $\left(\mathrm{SiO}_{2}\right)$ content of $\mathrm{BOF}$ slag ranged from 7 to $18 \%$, the $\mathrm{Al}_{2} \mathrm{O}_{3}$ and $\mathrm{MgO}$ contents $0.5-4 \%$ and $0.4-14 \%$, respectively. The free lime content was as high as $12 \%$. Very high $\mathrm{CaO}$ content $(\mathrm{CaO}>35 \%)$ was typical of BOF slag and was as a result of large quantities of lime or dolomotic lime used during the process of conversion from iron to steel. From Table1, there was a similar chemical composition between electric arc furnace (EAF) and BOF slags. The chemical composition of the former, produced essentially from steel scrap recycling process depended significantly on the properties of the recycled steel. Compared to BOF slags, the typical main chemical constituents of EAF slags were $\mathrm{FeO}, \mathrm{CaO}, \mathrm{SiO}_{2}, \mathrm{Al}_{2} \mathrm{O}_{3}$, and $\mathrm{MgO}$, occurring in the ranges of $10-40 \%, 22-60 \%, 6-34 \%$, 3-14\%, and 3-13\%, respectively, with a wide variation. $\mathrm{MgO}, \mathrm{MnO}$, and $\mathrm{SO}_{3}$ oxidized impurities were minor components of EAF slags. Free $\mathrm{CaO}$ and $\mathrm{MgO}$ along with other complex minerals and solid solutions of $\mathrm{CaO}, \mathrm{FeO}$, and $\mathrm{MgO}$ were also constituents of EAF slags. FeO content of EAF slags generated from stainless steel production processes were as low as $2 \%$ (Shen et al (2004). During the steel refining process, different alloys were fed into the ladle to obtain the desired steel grade making the chemical composition of ladle slag to be highly dependent on the grade of steel produced. This accounted for the comparatively high variable chemical composition of ladle slag than BOF slag. The FeO content of ladle slag was much lower $(<10 \%)$ than that of EAF and BOF slags. The contents of $\mathrm{Al}_{2} \mathrm{O}_{3}$ and $\mathrm{CaO}$ were typically higher for ladle slags and that of $\mathrm{Fe}_{2} \mathrm{O}_{3}$, was low (1.6-3-3\%). These values were much lower than those composing DSC slag, for example, $\mathrm{Fe}_{2} \mathrm{O}_{3}(27.32 \%$ ) (refer to Table 1). Based on such investigation results steelmaking slag has been used in a number of industries particularly as a blast furnace feed; and in the lime and phosphate fertilizer industries.

Nigeria produces large volumes of solid industrial byproducts including steelmaking slag with potentials as industrial raw materials to conserve natural resources. This work therefore, investigated the geochemistry of the Delta Steel Company (DSC) slag using the X-ray fluorescence method to determine its potential use as ironmaking blastfurnace feed and as fertilizer.

\section{MATERIAL AND METHODOLOGY}

Sampling: Slag sampling was done by random spot hand picking of fifteen (15No) DSC dump slag samples (N7N21) for laboratory testing. Samples of each spot were put into thick but transparent bags and labeled with indelible ink. The fifteen (15) bulk size samples were finally taken to the laboratory for testing according to BS812 (Part 3, 1975:1988) Standard Specifications.

\section{1 Test sample preparation}

Blocks of each sample of slag were cut into suitable rock size specifications for the jaw crusher and the fly press using rock cutting machines. The latter produced gravel sized grades from which powders were produced by grinding $1 \mathrm{x} 30$ 
seconds in the Tema mill. The powders were then used to produce quenched glass discs for geochemical analysis by melting the powder with Johnson Matthey spectroflux 105 followed by air quenching. The melting with the flux was to overcome grain size and packing density influence on the emission of x-rays. Glass discs were used because they had a low absorption capacity for X-rays and reduced inter-element effects to such an extent that they did not influence the analysis (Ludwig and Richard, 1978). With the use of glass discs, different types of slag samples were analyzed using the same calibration factors and the achievement of accurate results.

\subsection{Laboratory Geochemical analysis of DSC slag}

The chemical oxide compositions of DSC slag samples were determined using the X-ray fluorescence (XRF) analysis method. The Phillips PW1212 XRF machine with a Chromium target tube was used for the analyses, set at operating conditions of $60 \mathrm{Kv}$ and $26 \mathrm{~mA}$.. The bulk chemistry of fifteen (15) glass disc samples of the slag, were analyzed. The bulk geochemical analyses results of the fifteen samples and the mean respectively, are presented on Table 2 and Table 3 .

\section{RESULTS AND DISCUSSION}

\subsection{Results}

\begin{tabular}{|c|c|c|c|c|c|c|c|c|c|c|}
\hline \multirow[t]{2}{*}{ Oxide \% } & \multicolumn{10}{|c|}{ DSC Slag Samples } \\
\hline & N7 & N8 & N9 & N10 & N12 & N13 & N14 & N17 & N19 & N21 \\
\hline $\mathrm{S}_{\mathrm{I}} \mathrm{O}_{2}$ & 2.42 & 21.64 & 19.74 & 19.52 & 19.20 & 19.27 & 19.72 & 20.19 & 18.18 & 18.25 \\
\hline $\mathrm{T}_{\mathrm{I}} \mathrm{O}_{2}$ & 0.42 & 0.46 & 0.42 & 0.39 & 0.40 & 0.41 & 0.45 & 0.44 & 0.42 & 0.41 \\
\hline $\mathrm{Al}_{2} \mathrm{O}_{3}$ & 5.16 & 5.92 & 5.95 & 5.25 & 4.59 & 5.42 & 5.00 & 5.50 & 5.63 & 5.55 \\
\hline $\mathrm{Fe}_{2} \mathrm{O}_{3}$ & 7.93 & 21.70 & 26.33 & 28.20 & 27.69 & 25.50 & 25.22 & 26.71 & 25.97 & 25.73 \\
\hline $\mathrm{Cr}_{2} \mathrm{O}_{3}$ & 0.05 & 0.10 & 0.00 & 0.00 & 0.06 & 0.04 & 0.06 & 0.01 & 0.40 & 0.40 \\
\hline $\mathrm{MnO}$ & 1.67 & 1.33 & 2.03 & 1.03 & 1.82 & 1.53 & 1.46 & 1.18 & 1.23 & 1.26 \\
\hline $\mathrm{MgO}$ & 7.94 & 9.65 & 10.95 & 9.00 & 7.41 & 9.68 & 8.02 & 7.52 & 12.37 & 12.54 \\
\hline $\mathrm{CaO}$ & 44.20 & 39.57 & 35.50 & 37.96 & 38.96 & 37.92 & 38.25 & 39.88 & 36.40 & 35.82 \\
\hline $\mathrm{Na}_{2} \mathrm{O}$ & 0.00 & 0.00 & 0.00 & 0.00 & 0.00 & 0.00 & 0.00 & 0.00 & 0.00 & 0.00 \\
\hline $\mathrm{K}_{2} \mathrm{O}$ & 0.03 & 0.06 & 0.05 & 0.08 & 0.04 & 0.08 & 0.04 & 0.03 & 0.02 & 0.03 \\
\hline $\mathrm{P}_{2} \mathrm{O}_{5}$ & 0.62 & 0.51 & 0.53 & 0.60 & 0.77 & 0.57 & 0.56 & 0.46 & 0.39 & 0.60 \\
\hline $\mathrm{SO}_{3}$ & 0.06 & 0.14 & 0.10 & 0.08 & 0.03 & 0.00 & 0.04 & 0.02 & 0.00 & 0.00 \\
\hline
\end{tabular}

The XRF analyses results (Oxide\%) are presented in Table 2 and Table 3, followed by discussions.

Table 2 Geochemistry of DSC Slag selected samples (Oxide \%)

Table 3. DSC slag mean, minimum and maximum Geochemistry (Oxide \%)

\begin{tabular}{|l|r|r|r|r|} 
Field & \multicolumn{1}{|c|}{ Mean } & \multicolumn{1}{c|}{ Std. dev } & \multicolumn{1}{c|}{ Min } & \multicolumn{1}{c|}{ Max } \\
\hline $\mathrm{SiO}_{2}$ & 19.861 & 1.331 & 18.180 & 22.420 \\
\hline $\mathrm{Al}_{2} \mathrm{O}_{3}$ & 5.426 & 0.374 & 4.590 & 6.000 \\
\hline $\mathrm{Fe}_{2} \mathrm{O}_{3}$ & 27.323 & 5.402 & 17.930 & 41.000 \\
\hline $\mathrm{Cr}_{2} \mathrm{O}_{3}$ & 0.168 & 0.184 & 0.000 & 0.450 \\
\hline $\mathrm{MnO}$ & 1,456 & 0.296 & 1.030 & 2.030 \\
\hline $\mathrm{MgO}$ & 9.766 & 2.171 & 7.050 & 13.430 \\
\hline $\mathrm{CaO}$ & 36.623 & 4.227 & 27.230 & 44.200 \\
\hline $\mathrm{Na} 2 \mathrm{O}$ & 0.00 & 0.00 & 0.00 & 0.00 \\
\hline $\mathrm{K}_{2} \mathrm{O}$ & 0.05 & 0.02 & 0.02 & 0.08 \\
\hline $\mathrm{P}_{2} \mathrm{O}_{5}$ & 0.565 & 0.078 & 0.440 & 0.770 \\
\hline $\mathrm{SO}_{3}$ & 0.039 & 0.043 & 0.000 & 0.140 \\
$\mathrm{TiO}_{2}$ & 0.423 & 0.022 & 0.390 & 0.460 \\
\hline
\end{tabular}

\subsection{Discussion}

DSC slag had high element (oxide\%) content and wide samples compositional variations (refer to Table 2. Table 3 presents the mean per centage element oxide composition of the slag. Concentrations of the major components were $\mathrm{CaO}(36.62 \%), \mathrm{Fe}_{2} \mathrm{O}_{3}(27.32 \%]$ and $\mathrm{SiO}_{2}(19.86 \%)$, ranging between (35.82\% and 44.20\%), (17.935 and 28.20\%), and $(19.25 \%$ and $22.42 \%)$ respectively. Constituents of lower concentrations were, $\mathrm{MgO}(9.77 \%), \mathrm{Al}_{2} \mathrm{O}_{3}(5.43 \%)$ and $\mathrm{MnO}(1.46 \%)$ ranging between (7.525 and 12.54\%), (5.165 and 5.95\%) respectively, all the constituents contents occurring in that descending order in each sample. This showed great concentration variations in the slag samples. The 
coefficient of variation was greatest with $\mathrm{Cr}_{2} \mathrm{O}_{3}(94.74 \%)$ and $\mathrm{MnO}(20.55 \%)$. This elemental coefficient of variation of DSC slag investigated, disagreed with those observed in literature by Thom and Wood, (1973), (Joseph and Haddad, 1975) with results of greatest values $\left(\mathrm{Cr}_{2} \mathrm{O}_{3}(28.1 \%)\right.$ and $\left(\mathrm{P}_{2} \mathrm{O}_{5}(22.6 \%)\right.$. This indicated that, there was thus a general higher co-efficient of oxide variation in DSC slag except, $\mathrm{SiO}_{2}$ and $\mathrm{Al}_{2} \mathrm{O}_{3}$. The slag had some significant amount of $\mathrm{K}_{2} \mathrm{O}(0.05 \%)$. The greater oxide composition variation in DSC slag was attributable to the particular direct reduction (DRI) process of steel/slag production.

\subsection{Comparison of dsc slag xrf analyses and literature results.}

The comparative XRF analyses results for other steelmaking slags and that of DSC slag are presented in Table 1. High $\mathrm{Fe}_{2} \mathrm{O}_{3}$ content of DSC slag may be due to the presence of $\mathrm{Fe}$ in the elemental state. The literature observed major constituent of slags that have been used as blastfurnace feed and as fertilizer were $\mathrm{CaO}(30-60 \%)$ [Lee, 1974; Pugh and Fletcher; Emery, 1977; Yildirim and Perez, 2011). Iron oxide and silica were the other major components. With a CaO content range of $27.23 \%$ and $44.20 \%$ (refer to Tables 3), DSC slag falls just a little outside this range of values of $30-60$ per cent. However, the mean value of $\mathrm{CaO}$ content (36.62\%) in the slag brought it closer to mixed Electric Arc/BOP steel slag values of $\mathrm{CaO}(35.60 \%)$ [Eggleston (1985)]. The proportions of the other two major constituents $\mathrm{Fe}_{2} \mathrm{O}_{3}(27.32 \%)$ and $\mathrm{SiO}_{2} 19.86 \%$ also vary widely from literature values of $\mathrm{Fe}_{2} \mathrm{O}_{3}\left(1.6 \%-38.6 \%\right.$ and $\mathrm{SiO}_{2}(2 \%-35 \%)$, refer to Table 1 . This indicated that DSC direct reduction steel making slag, had great industrial potentials within the family of steelmaking slags, particularly for use as blastfurnace feed and fertilizer (Das et al. 2007); Dippenaar (2007); Branco and Colla (2012)

$\mathrm{CaO}, \mathrm{Fe}_{2} \mathrm{O}_{3}, \mathrm{SiO}_{2}, \mathrm{MgO}, \mathrm{Al}_{2} \mathrm{O}_{3}, \mathrm{TiO}_{2}, \mathrm{P}_{2} \mathrm{O}_{5}$, and $\mathrm{SO}_{3}$, detected in the slag may have come from iron ore, burnt lime and hydrated lime used directly or indirectly in the direct reduction process of steel/slag production whilst the scrap iron may be the sole source of $\mathrm{TiO}_{2}, \mathrm{MnO}$ and $\mathrm{Cr}_{2} \mathrm{O}_{3}$, which may have leaked into the slag. All the above elements detected in all the fifteen slag samples though in varying amounts indicated that there was some difference between direct reduction (DR) steelmaking slag and cement clinkers in terms of chemistry.

\subsection{DSC slag use as a blastfurnace feed}

DSC slag had high contents of lime $[\mathrm{CaO}(36.62 \%)$,$] iron \left[\mathrm{Fe}_{2} \mathrm{O}_{3}(27.32 \%)\right]$ and silica $\left[\mathrm{SiO}_{2}(19.86 \%)\right]$ magnesia $[\mathrm{MgO}-$ $9.77 \%]$ and alumina $\left[\left(\mathrm{Al}_{2} \mathrm{O}_{3}(5.43 \%) ;\right]\right.$ and minor contents of manganese [MnO-1.46\%], in DSC slag as shown in Tables 1,2 and 3 respectively. The high contents of $\mathrm{CaO}, \mathrm{Fe}_{2} \mathrm{O}_{3}$ and $\mathrm{SiO}_{2}$ are the major constituents required of a blastfurnace iron making feed. DSC slag as a flux can reduce the iron production temperature in the blastfurnace, $\mathrm{Fe}_{2} \mathrm{O}_{3}$ of the slag can be reduced to $\mathrm{Fe}$ increasing the presence of $\mathrm{Fe}, \mathrm{CaO}$ can react with $\mathrm{SiO}_{2}$ not needed in the Iron to produce silicates during the ironmaking process in the blastfurnace (Rayner-Canham and Overton (2006), Science Aid (2007).

The presence of $\mathrm{MnO}$ could have been a disadvantage because this could probably create the problem of causing refractory lining destruction if used as a blast furnace feed resulting in possible production of off-quality hot metal. But the content of $\mathrm{MnO}(1.46 \%)$ is acceptably low minimizing the possible negative effect and of no disadvantage for use as a blast furnace feed. Also, a possible disadvantage of $\mathrm{MnO}$ presence is overcome by the possible reduction in manganese addition cost during ladle alloying of steel when the slag is used as feed material. The slag therefore qualifies for use as a blastfurnace feed.

\subsection{DSC slag use as fertilizer}

The presence of $\mathrm{MgO}, \mathrm{MnO}, \mathrm{Cr}_{2} \mathrm{O}_{3}(\mathrm{Cr}), \mathrm{P}_{2} \mathrm{O}_{5}$ and $\mathrm{SO}_{3}$ can be considered very useful to the slag because they can contribute to the stabilization of beta-belite $\left(\beta-\mathrm{C}_{2} \mathrm{~S}\right)$, the most important dicalcium silicate mineral phase polymorph which has high content of $\mathrm{CaO}$ and $\mathrm{SiO}_{2}(\mathrm{Ca}$ and $\mathrm{Si}$ ) suitable for plants in soil (Thilo and Funk, 1953; Savant et al., 1999; Motz and Geiseler, 2001). The high lime $(\mathrm{CaO})$ content present qualifies the slag as a lime fertilizer apart from the lime combined phosphorus in the slag, useful as a phosphate fertilizer material. DSC slag can be efficient in soil neutralization and thus used as a soil neutralizer. The slag being basic, can incresae K, Ca and Mg in soils (Rodriguez et al. (1994); Kühn et al., (2006); Negim et al., 2010) The siliceous liming materials can improve soil structure and reduce fungal infections. This can lead to a better yeild of the crops, soil protection and reduction of natural resources consumption around the company area (Hiltunen and Hiltunen, 2004). DSC slag is $\mathrm{SiO}_{2}$ rich which can be used to develop potassium silicate fertilizer and used as silica fertilizer to increase the resistance of rice to various diseases and vermin (Tatsuhito and Kazuya, 2006). The presence of $\mathrm{K}_{2} \mathrm{O}$ can make it suitable as a ready source of potassium to crops as a fertilizer. The high basicity of DSC slag makes it suitable as fertilizer to condition acid soils by increasing the $\mathrm{pH}$.

\section{CONCLUSION}

This investigation has shown the rich bulk chemistry of the slag in $\mathrm{CaO}(36.62 \%), \mathrm{Fe}_{2} \mathrm{O}_{3}(27.32 \%), \mathrm{SiO}_{2}(19.8 \% 6)$, $\mathrm{MgO}(9.77 \%), \mathrm{Al}_{2} \mathrm{O}_{3}(5.43 \%), \mathrm{MnO}(1.46 \%), \mathrm{TiO}_{2}(0.42 \%), \mathrm{Cr}_{2} \mathrm{O}_{3}(0.17 \%), \mathrm{P}_{2} \mathrm{O}_{5}(0.53 \%)$, and $\mathrm{SO}_{3}(0.04 \%)$. These are essential for use in the blastfurnace and as fertilizer. DSC slag is therefore valuable as an iron making blastfurnace feed and for use as lime, silicate and phosphate fertilizers. The results from this research should encourage the continuous production, recycling and use of the slag and other solid industrial by-products as industrial minerals. It would contribute to conserving natural resources and improve environment aesthetics. 


\section{REFERENCES}

- Advances in Civil Engineering, Vol. 2011, Article ID 463638, 13pp., 2011.

- Atwell, J. S. F: "Some properties of ground granulated slag and cement", In Proceedings of Institute of Civil Engineering Vol. 57 part 2 June, pp. 233-250, 1974.

- Barton, W.R.: 1975. Slag Industrial Minerals and Rocks, Fourth Edition, Lefond S.J., Editor, AIME, New York, 1975.

- Blunk, G, Geiseler, J., Use of steelmaking slags, represented by selected examples, Stahl and Eisen, Vol. 100, N0 3 Feb. 11, pp. 118-123, 1980.

- Branca, T. A., Colla, V., Scuola Superiore Sant'Anna- PERCRO - TeCIP Institute, Italy, 2012.

- Das, B. Prakash, S. Reddy, P. S. R., Misra, V. N., 2007. An overview of utilization of slag and sludge from steel industries, Resources, Conservation and Recycling, Vol. 50, No. 1, pp. 40-57, 2007.

- Dippenaar, R.," Industrial uses of slag - The use and re-use of iron and steelmaking slags", In proceedings of VII International Conference on Molten Slags and Salts, The South African Institute of mining and Metallurgy, 2004.

- Emery, J. J., "Slags as Industrial Minerals", In $3^{\text {rd }}$ Industrial Minerals International congress pp. 127-142, 1977.

- Geiseler, J., Use of steelworks slag in Europe, Waste Management, vol. 16, no. 1-3, pp. 59-63, 1996.

- Kristmann, M., Portland cement clinker mineralogical and chemical investigation. (Part 1 and II). Cement and Concrete Research. 7, pp. 649-658, 1977.

- Kühn, M., Spiegel, H., Lopez, A,. F., Rex, M., Erdmann, R., Sustainable agriculture using blast furnace and steel slags as liming agents, European Commission, Luxembourg, INTERNATIONAL 2006.

- Medland, J., Portland cement clinkers, mineralogical and chemical investigation, University of Hull, unpublished Ph.D Thesis, 1983.

- Motz, H., Geiseler, J., Products of steel slags an opportunity to save natural resources, Waste Management, vol. 21, no. 3, pp. 285-293, 2001.

- Negim, O., Eloifi, B., Mench, M., Bes, C., Gaste, H., Montelica-Heino, M., Le Coustumer, P., Effect of basic slag addition on soil properties, growth and leaf mineral, www.intechopen.com, 2010.

- Piatak, N. M., Parsons, M. B., Seal, R. R., Characteristics and Environment aspects of iron and steelmaking slags, Applied Geochemistry, Elsevier, 2015

- Piret, J. and Lesgardeur A., "Utilization possibilities of LD slags, Abstract," In International Conference on Slags, Scoria and Waste Products. Mons, 1975.

- Rayner-Canham, Overton, Descriptive Inorganic Chemistry, Fourth Edition, New York: W. H. Freeman and Company, pp. 534-535, 2006.

- Regourd, M., Guinier, A., "The crystal chemistry of the constituents of Portland cement clinker," In Proceedings of VIth. International. Symposium. Chemistry of Cement., Vol. 1 (Moscow).,pp. 25-52, 1974.

- Rodriguez, M., F. A. Lopez, Pinto, M., Balcazar, N., Besga, G., 1994. Basic Linz-Donawitz slag as a liming agent for pastureland. Agronomy Journal, Vol. 86, No. 5, pp. 904- 909, 1994.

- $\quad$ Science Aid. "Blast Furnace". Retrieved,12-30,2007.

- Shen, H. Forssberg, E., Nordström, U., Physicochemical and mineralogical properties of stainless steel slags oriented to metal recovery, Resources, Conservation and Recycling, vol. 40, no. 3, pp. 245-271,2004.

- Shi, C., "Steel slag - its production, processing, characteristics, and cementitious properties", Journal of Materials in Civil Engineering, vol. 16, no. 3, pp. 230-236, 2004.

- Scott, P.W., Critchley, S.R., Wilkinson, F.C.F., The chemistry and mineralogy of some granulated and pelletized blast furnace slags. Mineralogical Magazine, Vol,50,pp141-7, 1986.

- Tatsuhito, T., Kazuya, Y, New Applications for Iron and Steelmaking Slag.

- Thilo, E., Funk, H., 1959., Effects of small amounts of alkalis on the $\beta-\gamma$ inversion in $\mathrm{C}_{2} \mathrm{~S}$.., Z. Anorg. Allgem. Chem. ,273, pp.1-2, 28-40, 1959.

- Yamaguchi, G., Takagi, S., "The analysis of Portland cement clinker", In proceedings of the Vth International Conference of Chemistry of. Cement. (Tokyo). Part 1, pp. 181-225, 1968.

- Yildirim, I. Z., Prezzi, M., 2011. Chemical, Mineralogical, and Morphological Properties of Steel Slag. 2011 